\title{
Comparación entre el comportamiento mecánico a tracción, fractura y fatiga de armaduras de refuerzo fabricadas con distintos tipos de acero
}

\section{A comparison of tensile, fracture and fatigue mechanical behaviour of structural reinforcing bars made with different steels}

\author{
C. Rodríguez(*), F. J. Belzunce(*), A. F. Canteli(*)
}

Recepción / Received: 14-V-12

Aceptación / Accepted: 25-I-13

\section{RESUMEN}

El uso de aceros inoxidables austeníticos como armaduras de refuerzo es una opción cada vez más utilizada en estructuras de hormigón armado expuestas a ambientes agresivos y especialmente en las que han de trabajar en ambientes marinos. Lo mismo cabe decir de las armaduras de acero inoxidable dúplex, si bien su uso es menor, debido sobre todo a que su inclusión en la normativa aplicable al armado de hormigón se retrasó 10 años con respecto a los inoxidables austeníticos y, consecuentemente, su comportamiento en servicio es menos conocido.

En este trabajo se analiza el comportamiento mecánico, incluyendo fractura y fatiga, así como la resistencia a la corrosión en medios que simulan un hormigón contaminado de cloruros, de armaduras fabricadas tanto con aceros inoxidables austeníticos (304LN y 316LN) como dúplex (D2205). Asimismo se han caracterizado armaduras convencionales de acero al carbono (B500SD) como comparación. Las armaduras de acero inoxidable muestran unas propiedades mecánicas similares e incluso superiores a las de acero al carbono, exhibiendo además una ductilidad y una resistencia a la corrosión en un medio alcalino salino claramente ventajosas.

Palabras clave: barras de refuerzo; acero inoxidable; fatiga; fractura; corrosión.

\section{ABSTRACT}

The use of austenitic stainless steels as rebar is an option increasingly used in reinforced concrete structures exposed to aggressive environments and especially those that have to work in marine environments. The same is true for duplex stainless steel rebars, although nowadays they have a lower use, mainly due to the fact that their inclusion in the reinforced concrete standards was delayed 10 years compared to austenitic stainless steel ones, and consequently their in-service behavior is not as well known.

A study of the mechanical properties, including fracture toughness, fatigue behaviour and corrosion resistance in saline alkaline environments of austenitic (AISI 304LN and 316LN) and duplex (D2205) stainless steel reinforcing bars was performed in this work. Bars made on a high ductility carbon steel (B500SD) that are normally used to reinforce concrete were also characterized and used as a comparison. Stainless steel reinforcing bars show mechanical properties at least similar but usually higher than one of the best carbon steel re-bars (B500SD), along with a significantly higher ductility and, of course, much better corrosion behaviour in saline alkaline environments.

Keywords: reinforcing bars; stainless steels; fatigue; fracture; corrosion.

(*) Universidad de Oviedo.

Persona de contacto / Corresponding author. cristina@uniovi.es 


\section{INTRODUCCIÓN}

Aunque las armaduras de acero al carbono son las más utilizadas en el refuerzo del hormigón, es bien conocida su baja resistencia a la corrosión en ambientes salinos, como es el caso de las estructuras que deban trabajar en zonas cercanas al mar o en presencia de sales utilizadas para el deshielo en climas fríos. En estas condiciones, y aunque el hormigón proporciona una cierta protección a las armaduras, al cabo de un espacio de tiempo relativamente corto, el agua con iones cloruro penetra a través del recubrimiento de hormigón hasta llegar a las armaduras, provocando un rápido deterioro de la estructura.

En estos casos, y aunque existen otros métodos de protección contra la corrosión (1), el uso de armaduras de acero inoxidable en sustitución de las de acero al carbono es una opción cada vez más utilizada, al menos de las zonas más expuestas de las estructuras (2). Aunque el uso de acero inoxidable como refuerzo, encarece inicialmente el precio de la estructura (el precio del acero inoxidable es hoy en día entre 5 y 8 veces superior al del acero al carbono convencional), existen estudios que demuestran que su utilización supone un ahorro a largo plazo $(3,4)$. Esto es debido a que se elimina la necesidad de utilizar otros métodos de protección, como los revestimientos de las barras de refuerzo, el uso de capas de hormigón de recubrimiento más gruesas $y$, especialmente, al reducirse los costes de mantenimiento y rehabilitación. Por esta razón, el uso de barras de acero inoxidable como refuerzo se considera, en la actualidad, una opción de construcción óptima en el caso de estructuras expuestas y cuya vida útil deba ser superior a 75-100 años (5-7).

Hasta hace unos años la mayoría de los aceros inoxidables utilizados para el refuerzo del hormigón han sido los aceros austeníticos, en particular los aceros AISI grado 304LN y AISI grado $316 \mathrm{LN}$, que se caracterizan por poseer unos niveles muy bajos de carbono (para evitar fenómenos de corrosión intergranular y para mejorar la soldabilidad) y encontrarse aleados con nitrógeno (elemento que aumenta su resistencia mecánica).

En cuanto a los aceros inoxidables dúplex, puede decirse que su utilización como armadura en estructuras expuestas es cada vez más frecuente, aunque su uso sigue siendo todavía más reducido que el de los aceros austeníticos. Teniendo en cuenta que las armaduras de acero inoxidable dúplex presentan una resistencia mecánica similar e incluso superior a las fabricadas con aceros inoxidables austeníticos (8) junto con una más que aceptable resistencia a la corrosión en condiciones ambientales críticas, su menor utilización no parece estar justificada. La explicación a este hecho parece más bien estar basada en el menor conocimiento que ingenieros y técnicos poseen sobre el

\section{INTRODUCTION}

It has long been recognized that carbon steel reinforcing bars have a low resistance to corrosion in chloride-bearing environments, as it is the case in coastal structures or due to the use of de-iced salts in cold weather conditions. Although concrete provides protection to the embedded steel under the aforementioned conditions, the penetration of oxygen, water and chloride ions through the concrete gives way to a rapid deterioration of the structure.

In these cases, although there are other methods of protection against corrosion (1), the use of stainless steels as substitutes of carbon steels for the reinforcement of the more exposed zones of the structures is nowadays becoming more and more frequent (2). The use of stainless steels, although initially very expensive (stainless steel has nowadays a cost 5-8 times more expensive than uncoated carbon steel), offer cost savings in the long term, eliminating or reducing rebar coatings, the use of thicker concrete overlays, and especially maintenance and rehabilitation costs $(3,4)$ Today, the use of stainless steel reinforcing bars are considered an optimal construction option when a design life of 75-100 years is demanded and life-cycle cost analysis has to be taken into account (5-7).

Although, until now, most of the stainless steels used for the reinforcement of concrete have been the austenitic grades, in particular AISI 304LN and AISI 316LN, characterized by very low carbon levels (to prevent intergranular corrosion phenomena and to improve weldability) and nitrogen alloyed (to increase their mechanical strength), more recently, duplex stainless steels have also started to be used in these applications.

Taking into account that the duplex grades surpass austenitic ones in their strength properties and also have very good corrosion resistance under critical environmental conditions, the still low application of these grades in practical construction designs, is mainly justified because engineers and technicians do not have enough practical knowledge on the specific in-service behaviour of these materials. 
comportamiento en servicio de este tipo de aceros, cuyo uso no ha sido contemplado por la normativa aplicable hasta fechas relativamente recientes (9), mientras que la utilización de los grados austeníticos ya se incluía casi veinte años antes (10).

En un intento por clarificar la situación expuesta previamente, se ha realizado un amplio trabajo experimental con el fin de conocer mejor el comportamiento de armaduras fabricadas con distintos tipos de aceros inoxidables austeníticos (AISI 316LN y AISI 304LN) y dúplex (D2205). Además de determinar su comportamiento mecánico convencional (resistencia a la tracción y dureza) y su microestructura, se ha analizado su resistencia a la fractura, así como su comportamiento a fatiga y frente a la corrosión en un medio que simulaba un ambiente salino de tipo alcalino. Asimismo, se ha analizado el comportamiento de armaduras de acero al carbono de alta ductilidad y elevadas prestaciones mecánicas (B500SD), a modo de comparación.

\section{MATERIALES Y PROCEDIMIENTO EXPERIMENTAL}

\subsection{Materiales y proceso de fabricación}

Los materiales utilizados en este trabajo han sido dos aceros inoxidables austeníticos de los tipos AISI 304LN y AISI 316LN y un dúplex del tipo AISI 2205, que fueron suministrados por la empresa ROLDAN S.A. (Ponferrada, España) en forma de barras corrugadas de $16 \mathrm{~mm}$ de diámetro nominal, obtenidas por laminación en caliente. Así mismo y al objeto de utilizarlo como referencia, se analizó el comportamiento de un acero al carbono de alta ductilidad (B500SD) que, como los anteriores, también fue corrugado por laminación en caliente. La Tabla 1 recoge la composición química de las coladas correspondientes a cada uno de los aceros utilizados.
This reticence can be considered normal as the specific standards for the austenitic stainless steels reinforcing bars have been developed in the course of the last 20 years $(8,9,10)$, while the relative to the duplex stainless steels is now just initiating (9).

In an attempt to clarify the situation previously exposed, a wide experimental work was made with the aim to have a better knowledge of the mechanical behaviour of austenitic (AISI 316LN and AISI 304LN) and duplex stainless steels (D2205) corrugated reinforcing bars. Besides the determination of their conventional mechanical properties and microstructures, their behaviour under fracture and fatigue conditions and, also, under corrosion in alkaline environments have also been determined. On the other hand, also a carbon steel reinforcing bar with very good mechanical properties and high ductility (B500SD) has been characterized as a reference.

\section{MATERIALS AND EXPERIMENTAL PROCEDURE}

\subsection{Materials and manufacture processes}

The materials used in this study were two austenitic stainless steels (AISI 304 LN and AISI 316LN) and a duplex stainless steel (D2205), that were furnished by ROLDAN S.A. (Ponferrada, Spain) as hot rolled and ribbed bars, with a nominal diameter of $16 \mathrm{~mm}$. Furthermore, and in order to use it as a reference, the behavior of a hot rolled high ductility carbon steel re-bar (B500SD) was also analyzed. The chemical composition of all the analysed grades is shown in Table 1.

Tabla 1 / Table 1

Composición química de los aceros utilizados (\% peso). Chemical composition of the steels (wt\%).

\begin{tabular}{|c|c|c|c|c|c|c|c|c|c|c|}
\hline \% Peso / wt \% & $\mathbf{C}$ & $\mathbf{S i}$ & $\mathbf{M n}$ & $\mathbf{C r}$ & $\mathbf{N i}$ & $\mathbf{M o}$ & $\mathbf{N}$ & $\mathbf{C u}$ & $\mathbf{S}$ & $\mathrm{Ti}$ \\
\hline 304LN & 0.023 & 0.38 & 1.49 & 18.55 & 8.77 & 0.21 & 0.176 & 0.18 & 0.022 & 0.003 \\
\hline 316LN & 0.030 & 0.36 & 1.31 & 17.62 & 11.70 & 2.87 & 0.182 & 0.10 & 0.004 & 0.005 \\
\hline D2205 & 0.021 & 0.45 & 1.75 & 22.25 & 4.79 & 3.28 & 0.165 & 0.30 & 0.004 & 0.07 \\
\hline B500SD & 0.19 & 0.24 & 0.95 & 0.11 & 0.13 & 0.02 & - & 0.34 & 0.025 & - \\
\hline
\end{tabular}

Como puede observarse, todos los aceros inoxidables se caracterizan por un contenido en carbono muy bajo y la presencia de nitrógeno como elemento endurecedor. Asimismo, cabe destacar la presencia de titanio en un porcentaje más alto que el meramente residual en el acero inoxidable dúplex. Por último, nótese el elevado porcentaje de azufre presente en los aceros 304LN y B500SD.
All the stainless steels had very low carbon contents and nitrogen additions in order to increase their strength. It is also worth to highlight the presence of titanium in the duplex steel, in a higher content than the corresponding to a residual element. Finally, 304LN and B500SD steels had significant sulphur contents. 
La geometría general de los corrugados utilizados se muestra en la Figura 1.
Figure 1 shows the general geometry of the corrugated bars.

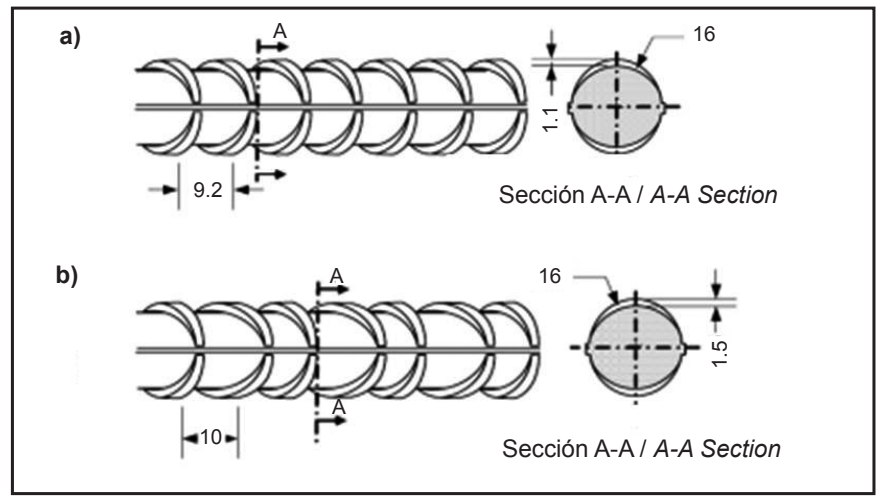

Figura 1. Geometría general de los corrugados: a) barras de acero inoxidable, b) barras de acero al carbono. Figure 1. Geometry of the reinforcing bars: a) stainless steel bars, b) carbon steel bars.

\subsection{Procedimiento experimental}

El análisis metalográfico se realizó mediante microscopía óptica, sobre muestras obtenidas de las barras tanto en dirección longitudinal como en dirección transversal y utilizando la norma ASTM E112-96 (11) para la medida del tamaño de grano. Las muestras se desbastaron en húmedo con papeles de $\mathrm{SiC}$, se pulieron con pasta de diamante de 6 y $1 \mu \mathrm{m}$ y, finalmente, se atacaron metalográficamente. Los aceros inoxidables austeníticos fueron atacados electrolíticamente, utilizando una solución acuosa con un $60 \%$ en volumen de ácido nítrico, un potencial de $1.2 \mathrm{~V}$ y un tiempo comprendido entre 1 y 2 minutos mientras que para el dúplex se utilizó una solución de 56 $\mathrm{g}$ de hidróxido potásico en $100 \mathrm{ml}$ de agua destilada, bajo un potencial de $2 \mathrm{~V}$ durante 3-5 segundos. Para el ataque metalográfico del acero al carbono se utilizó Nital al 4\%.

Los perfiles de dureza se obtuvieron utilizando un microdurómetro Vickers con carga de 500 gramos y siguiendo las recomendaciones de la norma ASTM E92 (12). Los ensayos de tracción se realizaron sobre trozos completos de barra, con una longitud de $200 \mathrm{~mm}$, de acuerdo con la normativa aplicable a este tipo de productos (13). En el caso de los aceros inoxidables, el límite elástico fue determinado mediante la realización de cargas y descargas sucesivas hasta alcanzar el 0,2\% de deformación, mientras que el correspondiente al acero al carbono coincide con la tensión media en la zona de cedencia de su curva tensión-deformación.

El análisis del comportamiento mecánico a fractura se ha realizado a través de las curvas J-R representativas de cada material, utilizando probetas de flexión en tres puntos (SENB) que fueron ensayadas en condiciones estáticas, siguiendo las recomendaciones del protocolo ESIS (14). Las probetas fueron extraídas de las barras

\subsection{Experimental procedure}

Metallographic analysis was performed by means of optical microscopy on samples taken from the bars, both in the longitudinal and the transverse direction, and the ASTM E112 standard (11) was used to the measurement of the grain size. These samples were ground and polished with 6 and $1 \mu \mathrm{m}$ diamond pastes, and finally etched. The austenitic stainless steels were electrolitically etched in an aqueous solution with $60 \%$ vol. of nitric acid, under 1.2 volts, during a time comprised between 1 and 2 minutes, and a solution of $56 \mathrm{~g}$ of $\mathrm{KOH}$ in $100 \mathrm{ml}$ of water, under 2 volts, during 3-5 seconds was used in the case of the duplex steel. The microstructure of the carbon steel was revealed using the $4 \%$ Nital reagent.

Hardness profiles were obtained using a Vickers microhardness tester under a load of $500 \mathrm{~g}$ and following the ASTM E92 standard (12) recommendations. Tensile tests were performed directly on the reinforcing bars using samples with a length of $200 \mathrm{~mm}$, in accordance with the standard applied to test these ribbed products (13). In the case of the stainless steels, the yield strength was determined by carrying out several load and unload processes until attaining a strain of $0.2 \%$, while the yield strength of the carbon steel was taken as the mean stress value of the yield zone of its stress-strain curve.

Representative J-integral crack growth resistant curves of the steels were determined using single-edge notched bend specimens (SENB) under static conditions according to the ESIS procedure (14). Specimen dimensions (WxBXL) were $55 \times 10 \times 10 \mathrm{~mm}$. Figure 2 shows the way these specimens were machined from the original 
corrugadas tal como se refleja en la Figura 2, y sus dimensiones $(\mathrm{W} \times \mathrm{BXL})$ fueron de $10 \times 10 \times 55 \mathrm{~mm}$. Todas las probetas fueron pre-agrietadas por fatiga hasta obtener una grieta cuya longitud " $a$ " fuese aproximadamente igual a $5 \mathrm{~mm}(\mathrm{a} / \mathrm{W}=0,5)$, utilizando para ello, una máquina de ensayos dinámica MTS de 100 kN de capacidad de carga. Tras el proceso de fatiga, y siguiendo las recomendaciones de la norma (14), todas las probetas fueron entalladas lateralmente con objeto de asegurar un estado de deformación plana a lo largo de todo el frente de grieta. Todas las curvas J-R fueron obtenidas mediante el método uniprobeta, utilizando un extensómetro de tipo COD, que colocado en la boca de la entalla, nos ha permitido obtener la longitud instantánea de la grieta en crecimiento a través de la variación de la flexibilidad de la probeta. En algunos casos, la longitud de la grieta en crecimiento obtenida por este método, fue cotejada con la real, a través de medidas físicas de la misma sobre la superficie de fractura utilizando un método de tintado progresivo del frente de grieta (15). reinforcing bars. All specimens were pre-cracked in fatigue using a dynamic MTS testing machine with a maximum load of $100 \mathrm{kN}$ and a load ratio $P_{\min } / P_{\max }=0.1$, in order to provide a crack length to width ratio, $a / W=0.5$. After the pre-cracking process, all the specimens were side grooved to a thickness reduction of $20 \%$ as recommended in the standard, in order to assure a strain stress state along the whole crack front during the test. All J-R curves were obtained by means of the single specimen method, using a COD type extensometer placed on the mouth of the notch, that has allowed us to obtain the instantaneous length of the growing crack through the variation of the flexibility of the specimen.In some cases, crack extensions were physically measured by means of the heat tinting method (15) in order to corroborate the accuracy of the procedure.

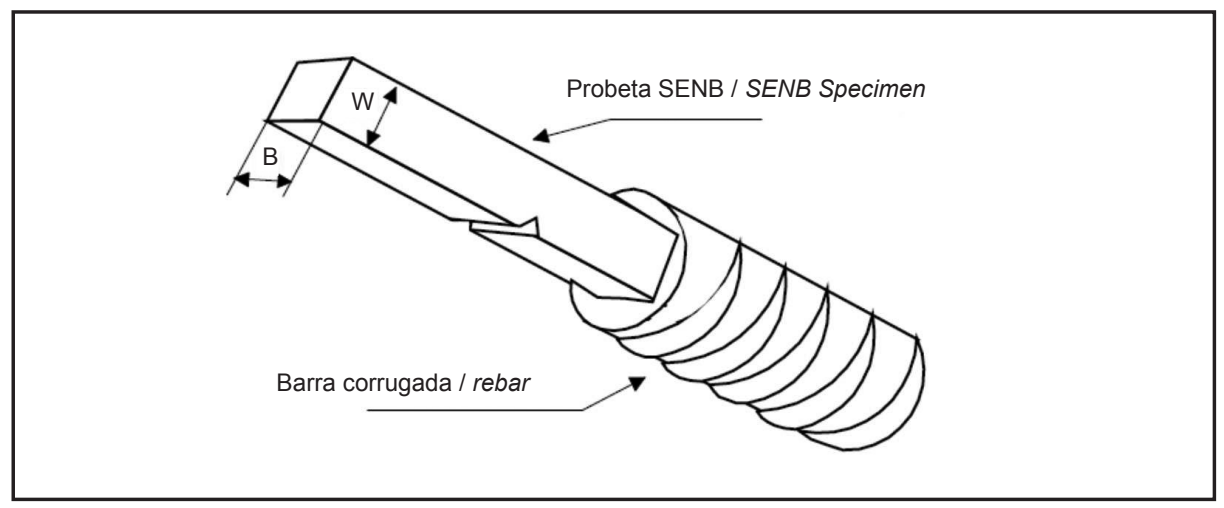

Figura 2. Geometría de las probetas de fractura SENB obtenidas a partir de las barras de refuerzo.

Figure 2. SENB fracture specimens machined from the reinforcing bars.

La caracterización a fatiga se realizó a través de la determinación de las curvas S-N mediante ensayos axiales de fatiga al aire bajo carga senoidal de amplitud constante utilizando una máquina de ensayos dinámicos MTS de $250 \mathrm{kN}$ de capacidad de carga. Atendiendo a la norma ISO CD15-630 (11), las probetas utilizadas eran trozos de barra, de modo que la longitud libre entre mordazas tenía una longitud igual a 16 veces su diámetro nominal. Con objeto de cubrir el campo S-N en la mayor medida posible, se efectuaron ensayos a diferentes niveles de amplitud de tensión $(\Delta \sigma)$, pero manteniendo fijo el valor de la tensión máxima para cada material. La estrategia de fijar la tensión máxima (16) en vez de la tensión media o la mínima, permite por un lado, ampliar mucho el campo $\mathrm{S}-\mathrm{N}$ en tracción, sin que lleguen a alcanzarse tensiones demasiado próximas al límite elástico, y por otro, trabajar en el lado de la seguridad, dado que para un mismo nivel de amplitud de tensión siempre se estará imponiendo una tensión media superior a la que resultaría si fijásemos la tensión mínima. De hecho, en los protocolos de ensayo
Fatigue tests were carried out in air under sinusoidal constant amplitude tensile loading in a MTS dynamic testing machine with a load capacity of $250 \mathrm{kN}$. According to the ISO CD15-630 standard (11), the tests were conducted on the "as-received" bars with a minimum free length between grips equal to 16 times their nominal diameter. Fatigue tests were carried out at different stress amplitude levels $(\Delta \sigma)$, obtained by varying the minimum stress, while maintaining constant the maximum stress in all the tests performed on each material. The use of a constant maximum stress (16) allows the extension of the $S-N$ field in tension without the risk of achieving stress levels that are too close to the material yield stress. On the other hand, the use of this test procedure also allowed us to work with a certain security factor, since for a particular stress amplitude level, the imposed mean stress will always be higher than the corresponding one which would be obtained when a constant minimum stress was used. In fact, in order to determine the fatigue strength of the rebars, current test standards proposed the use of a maximum 
para determinar la resistencia a fatiga de las normativas actuales para barras corrugadas se propone utilizar un valor de la tensión máxima de $0,6 \sigma^{\circ} \sigma_{y s}(6,7,10)$. En este caso, siguiendo la recomendación propuesta por Canteli et al. (16), y para conseguir valores suficientemente elevados de amplitud de tensión, que permitieran caracterizar todo el campo S-N, se ha fijado $\sigma_{\text {max }}=0,8 \cdot \sigma_{\mathrm{ys}}$. Como suele ser práctica habitual $(6,7)$, se consideró una duración límite para los ensayos de $2 \cdot 10^{6}$ ciclos, dándose éstos por finalizados una vez alcanzado este número de ciclos. Se obtienen de este modo los denominados "datos censurados" o "run outs", que corresponden a aquellas probetas que no han roto tras haber alcanzado el citado límite. Además, en los niveles inferiores de tensión se han realizado algunos ensayos de mayor duración (hasta 1,8·107 ciclos).

Los resultados experimentales de fatiga se analizaron utilizando el modelo estadístico de Castillo et al. (17). Este modelo define el campo S-N como una distribución acumulativa de la vida a fatiga $N$, para un rango de tensión $\Delta \sigma_{\mathrm{i}}$, del tipo [1]: stress value equal to $0.6^{\circ} \sigma_{y s}(6,7,10)$. In the present study, a $\sigma_{\max }=0.8^{\circ} \sigma_{y s}$ was employed, as proposed by Canteli et al. (16), in order to allow the characterization of the whole S-N field. Fatigue tests were considered finished after breakage of the specimen of the specimen or on reaching $2 \cdot 106$ cycles (run outs) $(6,7)$. Exceptionally, some specimens were tested for a longer time (until 1.8.10 cycles) under the lower stress levels.

The experimental fatigue results were analysed using the statistical model proposed by Castillo et al. (17). This model defines the $S-N$ field as the cumulative distribution function of the fatigue life, $\mathrm{N}$, for a given constant stress range $\Delta \sigma_{i}[1]$ :

$$
F\left(\log N_{i} ; \log \Delta \sigma_{i}\right)=1-\exp \left[-\left(\frac{(\log N-B) \cdot\left(\log \Delta \sigma_{i}-C\right)}{D}+E\right)^{A}\right]
$$

Donde $N$ es la vida a fatiga medida en ciclos, $\Delta \sigma_{\mathrm{i}}$ es la amplitud de tensión, $\mathrm{F}\left(\log \mathrm{N} ; \log \Delta \sigma_{\mathrm{i}}\right)$ es la probabilidad de fallo y $A, B, C, D, E$, son parámetros del modelo, que han de estimarse a partir de los resultados experimentales. En este modelo las curvas de isoprobabilidad que describen el campo S- $\mathrm{N}$, vienen definidas por una familia de hipérbolas equiláteras, cuya ecuación se puede obtener haciendo $\mathrm{P}=\mathrm{F}(\log N ; \log \Delta \sigma)[2]$ : where $\mathrm{N}$ is the mean fatigue life (cycles), $\Delta \sigma_{i}$ the stress range, $\mathrm{F}\left(\log \mathrm{N} ; \log \Delta \sigma_{i}\right)$ the failure probability and $\mathrm{A}, \mathrm{B}, \mathrm{C}$, $\mathrm{D} y \mathrm{E}$ are the unknown model parameters, which have to be adjusted by the experimental results. In this model, isoprobability curves describing the $S-N$ field are defined by a family of equilateral hyperbolas, whose equation is defined by $(P=F(\log N ; \log \Delta \sigma))[2]$ :

$$
\operatorname{gg} \mathrm{N}-\mathrm{B})(\log \Delta \sigma-\mathrm{C})=\mathrm{D}\left[[-\log (1-\mathrm{P})]^{1 / \mathrm{A}}-\mathrm{E}\right\rceil
$$

Finalmente, se determinó la resistencia a la corrosión de los diferentes aceros inoxidables mediante el ensayo de medida de la resistencia a la polarización, según la norma ASTM G59 (18). El medio corrosivo utilizado fue una solución acuosa de 0,3N KOH $+0,05 \mathrm{~N} \mathrm{NaOH}+3 w t \%$ $\mathrm{NaCl}$ en agua destilada, con un $\mathrm{pH}=13,2$, que simula las condiciones que imperan en el interior de un hormigón contaminado con iones cloruro (19).

Las muestras utilizadas fueron previamente desbastadas hasta el papel 600 , desengrasadas con acetona y finalmente lavadas con agua destilada. A continuación se introdujeron en el medio y se determinó su potencial de corrosión al cabo de 55 minutos de inmersión. El ensayo se llevó a cabo utilizando un potenciostato modelo Versatat II y una celda electroquímica modelo K0235 (EEG Instrument), con un electrodo de referencia $\mathrm{Ag} / \mathrm{AgCl}$ y una
Finally, the corrosion resistance at room temperature of the different stainless steels was determined by the measurement of their polarization resistances, according to ASTM G59 (18). The used corrosive medium was a $0.3 \mathrm{~N}$ $\mathrm{KOH}+0.05 \mathrm{~N} \mathrm{NaOH}+3 w t \% \mathrm{NaCl}$ aqueous solution in distilled water, with $\mathrm{pH}=13.2$. This medium is representative of a salt contaminated environment in the contact zone between the reinforcing bars and the concrete (19).

Samples were previously ground until a 600 grit paper, degreased with acetone and finally washed with distilled water. Afterwards, the samples were introduced into the medium and the corrosion potential was measured after 55 minutes. Corrosion tests were performed using a Versatat II potentiostat and a K0235 electrochemical cell (EEG Instrument), with an $\mathrm{Ag} / \mathrm{AgCl}$ reference electrode and using a scan rate of $0.6 \mathrm{~V} / \mathrm{h}$, from a voltage located 
velocidad de muestreo de 0,6 V/h, desde un voltaje situado $30 \mathrm{mV}$ por debajo del potencial de corrosión de cada muestra hasta $30 \mathrm{mV}$ por encima del citado valor.

De cada tipo de acero se realizaron cinco ensayos con diez repeticiones consecutivas en cada uno de ellos, lo que dará una idea aproximada del comportamiento frente a la corrosión del acero a lo largo del tiempo. Se ensayaros 5 probetas de cada uno de los aceros y se determinó el valor medio de la resistencia de polarización y su desviación típica.

\section{RESULTADOS Y DISCUSIÓN}

\subsection{Microestructura}

La Figura 3 recoge la microestructura general correspondiente a la sección transversal de cada uno de los aceros analizados.
$30 \mathrm{mV}$ below the corrosion potential of each sample until attaining $30 \mathrm{mV}$ above this value.

Five samples of each steel were tested and the average value and the standard deviation of the polarization resistance were determined.

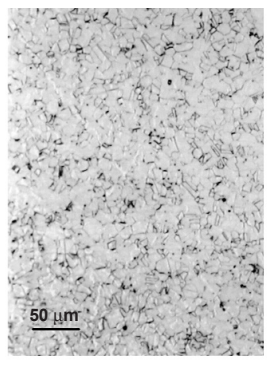

a)

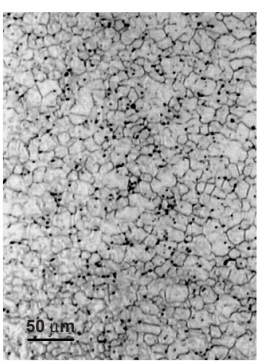

b)

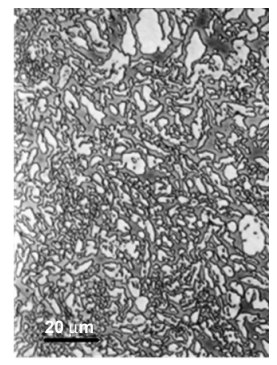

c)

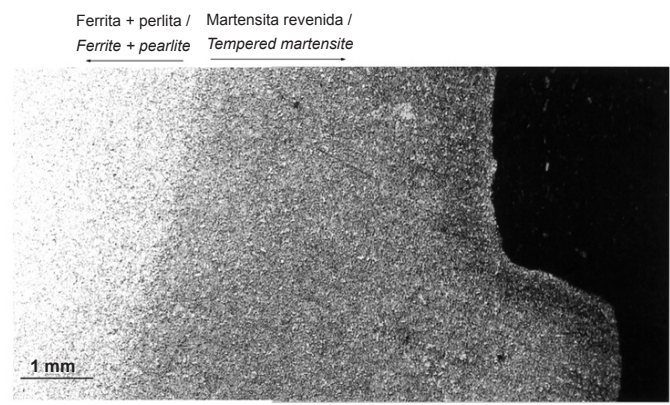

Figura 3. Microestructura de la sección transversal de las barras: a) $316 \mathrm{LN}$, b) $304 \mathrm{LN}$, c) D2205, d) B500SD Figure 3. Transversal section microstructure of the re-bars: a) $316 L N$, b) $304 L N$, c) D2205, d) B500SD

El análisis microestructural de los aceros 304LN y 316LN reflejó una estructura totalmente austenítica, con granos prácticamente equiáxicos, que no muestran una orientación preferente en la dirección de laminación. Por su parte, el acero D2205 muestra una microestructura dúplex con un porcentaje $\mathrm{a} / \mathrm{y}$ de aproximadamente 50/50. Es precisamente el carácter bifásico del acero dúplex el responsable de que los granos se encuentren preferentemente orientados en la dirección de laminación. En cuanto al acero al carbono, su microestructura sufre variaciones en función de la zona de la sección transversal analizada. La zona central del corrugado tiene una microestructura ferrito-perlítica, mientras que en la zona superficial, su estructura es de martensita revenida (debido al tratamiento de temple interrumpido y autorrevenido que estos corrugados sufren tras la laminación). En la Tabla 2 se refleja el tamaño de grano de los distintos aceros.
The metallographic analysis performed on the 304LN and 316LN stainless steels showed a fully austenitic microstructure provided with equiaxial grains, while the D2205 steel had a duplex $a / Y(50 / 50)$ microstructure with a grain orientation along the rolling direction. On the other hand, the carbon steel reinforcing bars showed an external region of tempered martensite (due to the interrupted quench, who give way to auto-tempering), whereas in the core the microstructure was ferrite+pearlite. Table 2 shows the average grain size of all these products. 
Tabla 2 / Table 2

Tamaño de grano de los aceros analizados. Grain size of the steels.

\begin{tabular}{|c|c|c|c|c|}
\hline Acero / Steel grade & A304LN & A316LN & D2205 & B500SD \\
\hline $\begin{array}{c}\text { Tamaño de grano / Grain size } \\
\text { (Número ASTM / ASTM Number) }\end{array}$ & 10.5 & 11.5 & $\begin{array}{l}\alpha=14 \\
\text { Y=15 }\end{array}$ & 7 \\
\hline
\end{tabular}

Merece la pena destacar la existencia, en todas las barras, de un grano apreciablemente más pequeño y deformado en las zonas cercanas a la superficie de las barras, especialmente en la región de la corruga, lo que se justifica en virtud de la mayor deformación y velocidad de enfriamiento (téngase en cuenta que estas regiones se encuentran en contacto directo con la herramienta de tallado) imperantes en las citadas regiones. Por su parte, en el acero dúplex se observó la presencia de nitruros de titanio, con una fracción volumétrica aproximada del $0,17 \%$ y un tamaño medio de $7 \mu \mathrm{m}$. Asimismo, los inoxidables austeníticos y el acero al carbono muestran inclusiones de sulfuro de manganeso, cuyo porcentaje es especialmente notorio en los aceros 304LN y en el B500SD, debido al alto contenido en azufre presente en los mismos (ver Tabla 1).

\subsection{Dureza y propiedades mecánicas a tracción}

La Figura 4 recoge los resultados de las líneas de dureza HV0,5 obtenidas a lo largo del diámetro de las barras de los distintos aceros. Todos los aceros muestran un claro endurecimiento superficial (sobre todo en la región de la corruga), que se extiende hasta una profundidad de 1-2 $\mathrm{mm}$. Excepto en estas regiones, la dureza en el resto de la barra era prácticamente constante. En la misma figura también puede apreciarse que la dureza media exhibida por el acero inoxidable dúplex es prácticamente un $50 \%$ superior a la del resto de materiales analizados.
All the bars had finer and more deformed grains in their most external region, especially in the ribbed zones, as a result of the higher strain and cooling rate suffered by these regions, which were in direct contact with the working rolls. Moreover, the presence of TiN precipitates is evident in the duplex steel bars $(0.17 \%$ vol. with a mean size of $7 \mu \mathrm{m}$ ) and the austenitic stainless steels and the carbon steel had a significant content of MnS inclusions (especially 304LN and B500SD, due to their higher sulphur content, see Table 1).

\subsection{Hardness and tensile mechanical properties}

Figure 4 shows the hardness profiles (HV0.5) measured along the diameter of these bars. All the steels had a clear surface hardening (rib region) until a depth of 1-2 $\mathrm{mm}$, while the hardness in the rest of the bars is nearly constant. It can also be seen in the same figure that the average hardness of the duplex stainless steel is almost $50 \%$ higher than that of the other steels.

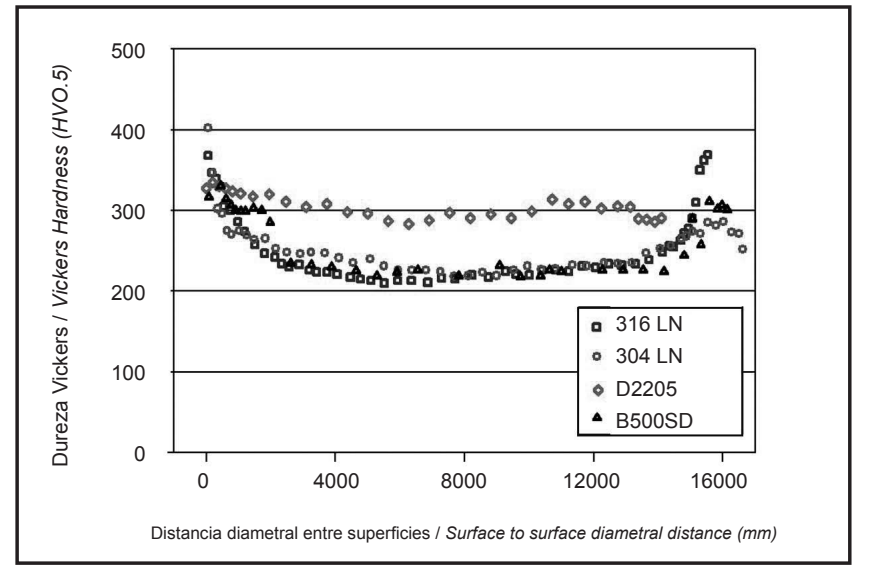

Figura 4. Perfiles de dureza HV0.5 obtenidos a lo largo del diámetro de las barras. Figure 4. HVO.5 hardness profiles along the diameter of the bars. 
Las propiedades mecánicas a tracción (Módulo elástico, $E$, límite elástico $\sigma_{y s \text {, }}$ resistencia a la tracción, $\sigma_{t s,}$ alargamiento, $A$, y estricción, Z), de los distintos aceros se muestran en la tabla 3 . Aunque el límite elástico de las barras de acero al carbono (B500SD) es superior al mostrado por los aceros inoxidables austeníticos, éstos últimos muestran una mayor resistencia mecánica y ductilidad, lo que les proporciona una mayor capacidad de endurecimiento por deformación (parámetro $\sigma_{t s} / \sigma_{y s}$ ). Se destaca igualmente la elevada resistencia de las barras de acero inoxidable dúplex, que aun así siguen manteniendo una elevada ductilidad.
Table 3 gives the average tensile mechanical properties of the reinforcing bars (elastic modulus, $\mathrm{E}$, yield stress, $\sigma_{y s}$ ultimate tensile strength, $\sigma_{t s,}$ elongation, $\mathrm{A}$, and reduction of area, Z). Although the yield stress of the carbon steel reinforcing bars is higher than that of the austenitic stainless steels, these latter have an ultimate tensile strength and a ductility higher than the carbon steel, as the austenitic steels also have a much larger strain hardening capacity (higher $\sigma_{t s} / \sigma_{y s}$ parameter). It is also worth to highlight the higher strength of the duplex reinforcing bars that, nevertheless, maintain a good ductility.

Tabla 3 / Table 3

Propiedades mecánicas a tracción de las barras corrugadas. Tensile mechanical properties of the reinforcing bars.

\begin{tabular}{|c|c|c|c|c|}
\hline Acero / Steel grade & B500SD & 304LN & 316LN & D2205 \\
\hline $\mathrm{E}(\mathrm{GPa})$ & 240 & 173 & 171 & 184 \\
\hline$\sigma_{\mathrm{ys}}(\mathrm{MPa})$ & 555 & 442 & 413 & 580 \\
\hline$\sigma_{\mathrm{ts}}(\mathrm{MPa})$ & 681 & 745 & 739 & 834 \\
\hline$\sigma_{\mathrm{ts}} / \sigma \mathrm{ys}$ & 1.23 & 1.68 & 1.79 & 1.44 \\
\hline $\mathrm{A}(\%)$ & 24 & 48 & 47 & 37 \\
\hline $\mathrm{Z}(\%)$ & 41 & 64 & 63 & 46 \\
\hline
\end{tabular}

\subsection{Comportamiento a fractura}

En la Figura 5 se muestran las curvas J-R correspondientes a los distintos aceros. Se ha de señalar, que una vez obtenidos los pares de datos J- $\Delta$ a que definían en cada caso la curva $J-R$ de los distintos materiales, se comprobó el incumplimiento generalizado de los requisitos que en cuanto a tamaño de probeta $\left(B, b_{0}>25 J_{0,2 / B L} / \sigma_{y}\right)$ y región de validez de la curva $J-R\left(J_{\max }, \Delta a_{\max }\right)$ imponen las distintas normas aplicables $(14,20)$. Ante la imposibilidad de solventar estos problemas (dada la geometría de las barras corrugadas de partida), y dado que lo que se pretende es realizar un estudio comparativo del comportamiento a fractura de los distintos aceros, se utilizarán de todos modos las curvas J-R y los parámetros $J_{0.2 / B L}$ (tabla 4) obtenidos experimentalmente para realizar dicha comparación. No obstante, los aceros inoxidables austeníticos (304LN y 316LN) también incumplen el requisito de cambio de pendiente de la curva $(\Delta J / \Delta a)$ que define la frontera entre la zona de enromamiento y la de crecimiento estable de la grieta. Este comportamiento, observado por otros investigadores en aceros similares (21), se debe a su elevada tenacidad, de tal modo que llega a alcanzarse la plastificación total del ligamento resistente antes de que la grieta comience a crecer. Por esta razón, en el caso de estos dos materiales únicamente se han representado los valores individuales $\mathrm{J}-\Delta \mathrm{a}$ obtenidos experimentalmente a modo de comparación, ya que no tiene objeto el ajuste de la curva.

\subsection{Fracture toughness behaviour}

Figure 5 shows the crack growth resistance curves (J-R curves) obtained from the four types of bars. Any of the tests have not fulfilled the standard requirements related to the specimen size $\left(\mathrm{B}, \mathrm{b}_{0}>25 \mathrm{~J}_{0.2 / \mathrm{B}} / \sigma_{y}\right)$ and curve $\mathrm{J}-\mathrm{R}$ validation region $\left(\mathrm{J}_{\max }, \Delta \mathrm{a}_{\max }\right)(14,20)$. As the size and geometry of the bars do not allow to solve these problems and as we only wanted to compare the fracture behaviour of these materials, the $\mathrm{J}_{0.2 / B L}$ parameter (table 4) directly obtained from the J-R curves was used for the aforementioned comparison. However, the austenitic stainless steels (304LN and $316 \mathrm{LN}$ ) also violate the requirement of the J-R curve slope change $(\Delta \mathrm{J} / \Delta \mathrm{a})$, that defines the boundary between the blunting zone and the stable crack growth one. This behaviour, already observed by other researchers on similar steels (21), is due to the very high fracture toughness of these austenitic steels, where the resistant ligament fully plastifies before the onset of the crack growth. For this reason, in the case of the austenitic steels, only the experimentally obtained individual $\mathrm{J}-\Delta \mathrm{a}$ values were represented. 
Tabla 4 / Table 4

Valores de tenacidad en el inicio del crecimiento estable de la grieta, J0,2/BL Crack initiation fracture toughness values, J0.2/BL

\begin{tabular}{|c|c|c|c|c|}
\hline Acero / Steel grade & B500SD & 304LN & 316LN. & D2205 \\
\hline$J_{0.21 \mathrm{BL}}\left(\mathrm{kJ} / \mathrm{m}^{2}\right)$ & 215 & $>500^{*}$ & $>500^{*}$ & 240 \\
\hline
\end{tabular}

(*) Estos valores no corresponden realmente a tenacidades en modo I dado que el crecimiento de la grieta en estos aceros se produce en modo mixto a través de un material completamente plastificado.

$\left(^{*}\right)$ These values do not correspond to valid fracture toughness data, since crack growth took place in a mixed mode through a fully plastified material

Al igual que ocurría con sus propiedades mecánicas a tracción, los aceros inoxidables austeníticos (304LN y $316 \mathrm{LN}$ ) muestran un comportamiento a fractura muy semejante, con una tenacidad muy superior a la de los aceros dúplex y al carbono. No obstante, la inferior tenacidad del acero dúplex respecto a los otros inoxidables, no se debe exclusivamente a las peculiares características mecánicas que le confiere su estructura bifásica, sino que en gran parte es debida a la presencia de nitruros de titanio en este acero. La rotura o descohesión de esta fase, muy dura y frágil, dispersa en la microestructura del acero, hace que los microhuecos típicos de la fractura dúctil crezcan más fácilmente y por tanto, que su tenacidad sea inferior (22). La Figura 6 recoge el aspecto de la superficie de fractura del acero dúplex (D2205), donde se aprecia la presencia de partículas de nitruro de titanio, fragmentadas y descohesionadas de la matriz durante el proceso de fractura.

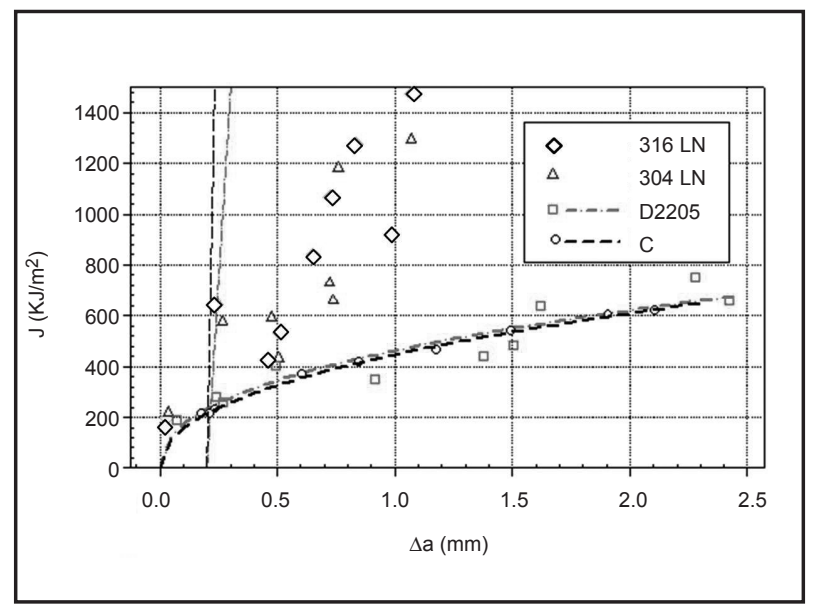

Figura 5. Curvas J-R de los diferentes aceros.

Figure 5. J-R curves of the different reinforcing bars.

\subsection{Comportamiento a fatiga}

La Figura 7 muestra, en una escala semilogarítmica, las curvas S-N medias ( $50 \%$ de probabilidad de fallo) correspondientes a las barras de acero inoxidable junto con la curva propuesta por la norma EN 10080 (23) para el caso del corrugado de carbono.
As in the case of the tensile mechanical properties, the austenitic stainless steels (304LN and 316LN) have a quite similar fracture behaviour, with a fracture toughness much higher than that of the duplex and carbon steels. Nevertheless, the significantly lower fracture toughness of the duplex stainless steel bars was also in this case motivated by the presence of TiN precipitates, due to the titanium contamination already mentioned (see Table 1). The fracture and de-cohesion of these hard and brittle precipitates, dispersed into the microstructure of the steel, promotes the nucleation and early growth of microvoids and reduces its fracture toughness (22). Figure 6 gives a general view of the fracture surface of the duplex stainless steel specimen. The presence of fragmented TiN particles and their de-cohesion from the matrix promoted by the ductile fracture process, giving way to very large voids, can be clearly observed.

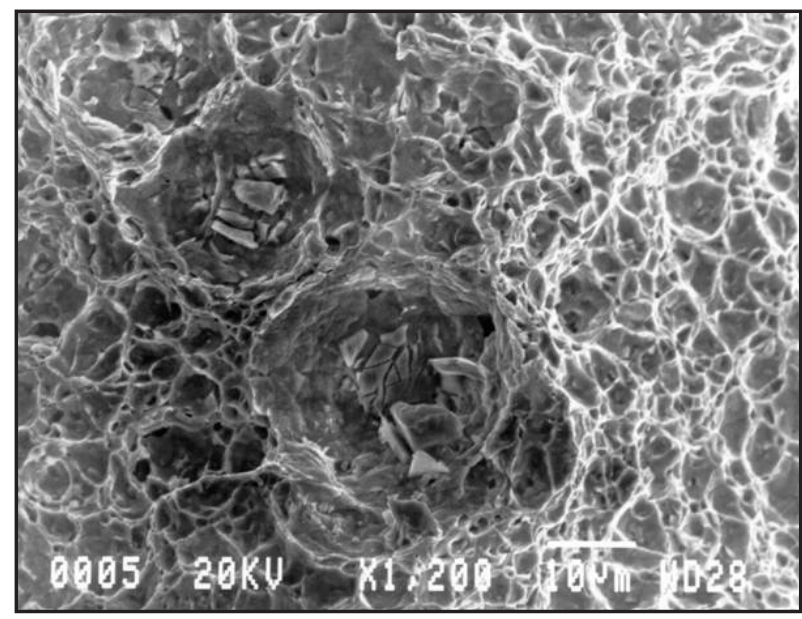

Figura 6. Superficie de fractura del acero inoxidable dúplex D2205.

Figure 6. Fracture surface of D2205 duplex steel.

\subsection{Fatigue behaviour}

Figure 7 shows, on a semi-logarithmic scale, the average $S-N$ curves (50\% probability of failure percentile) obtained with the stainless steel bars, together with the curve proposed by the EN 10080 standard (23), corresponding to the carbon steel re-bars. 
Teniendo en cuenta que las dos barras de acero inoxidable austenítico (304LN y 316LN) tenían la misma geometría y diámetro además de microestructuras y propiedades mecánicas muy similares, llama la atención el peor comportamiento a fatiga exhibido por las barras del acero 316LN, hecho que sin embargo puede ser explicado en virtud de la presencia, en la superficie de estas barras (Figura 8.a), de multitud de defectos superficiales de mayor longitud y agudeza $y$, consecuentemente, con un mayor efecto concentrador de la tensión, que los existentes en el acero 304LN (Figura 8.b).

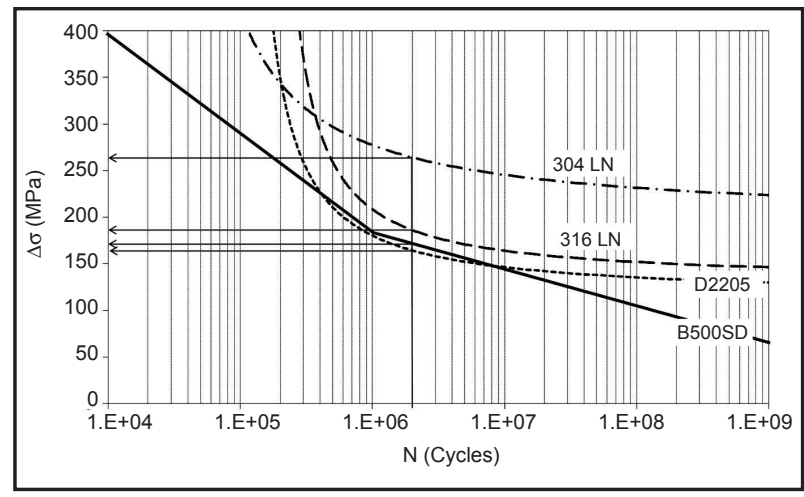

Figura 7. Curvas S-N de los corrugados para una probabilidad de fallo $(P=50 \%)$ obtenidas experimentalmente junto con la propuesta por la norma EN 10080 para corrugados de acero al carbono.

Figure 7. S- $N$ curves of the reinforcing bars $(P=50 \%)$ together with the curve proposed by the EN 10080 standard for carbon steel re-bars.

Por otro lado, el inferior comportamiento a fatiga de las barras de acero inoxidable dúplex se fundamentaría también en la presencia de defectos superficiales con un tamaño y longitud similar a los mostrados por las barras del 316LN, pero también contribuirían los precipitados de nitruro de titanio (TiN). Así, el examen mediante microscopía electrónica de barrido de las superficies de fractura de las barras de acero dúplex tras el ensayo de fatiga, permitió detectar en algunos casos, la existencia, en la zona de inicio de la grieta, de defectos microestructurales (huecos de geometría muy regular) que parecían denotar la anterior presencia de nitruros de titanio, que habrían sido arrancados durante el posterior crecimiento de la grieta (el análisis con microsonda detectó la presencia en dichas zonas de alúmina, compuesto sobre el que se nuclean y crecen los nitruros de titanio (24)). El elevado efecto concentrador de tensiones de los nitruros de titanio se debe tanto a su alta dureza como a su geometría angular, y explicaría el hecho de que el proceso de fatiga en el acero dúplex se inicie más rápidamente que en el resto de los materiales, que carecen de estos compuestos.

Otro factor importante a tener en cuenta es que los ensayos de fatiga fueron realizados bajo el criterio de utilizar siempre una tensión máxima fija en un $80 \%$ del límite
Reminding that the two stainless steels bars (304LN and $316 \mathrm{LN}$ ) had the same diameter and rib geometry and also microstructures and mechanical properties very similar, the lower fatigue behaviour of the $316 \mathrm{LN}$ bars can only be explained due to the presence of more acute and larger surface defects on these last bars (Figure 8.a), which gives way to a higher stress concentrator effect (Figure 8.b.).

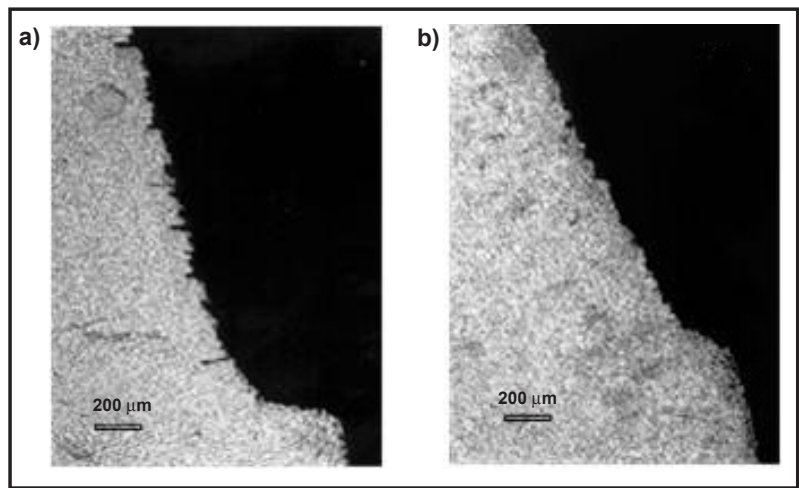

Figura 8. Defectos superficiales en las barras corrugadas: a) 316 LN, b) 304 LN.

Figure 8. Surface defects in reinforcing bars: a) $316 L N$, b) $304 L N$.

On the other hand, the poor fatigue behaviour of the duplex stainless steel bars can be also justified by the presence of surface defects, with a size and geometry of the same magnitude than the ones on the $316 \mathrm{LN}$, but also by the presence of TiN precipitates. Under the scanning electron microscope, voids with shapes denoting the previous existence of these precipitates were observed at the initiation region of the fatigue cracks and the chemical analysis of these zones carried out with an electron microprobe have detected the presence of alumina, which is known to be the compound where TiN nucleate (24). The high stress concentration effect of the TiN precipitates is due both to their very high hardness and their angular geometry, and this fact explains the early initiation of the fatigue process in the duplex stainless steel bars.

Nevertheless, another important factor needs to be considered, since in our case the fatigue tests were performed setting the maximum stress at $80 \%$ of the yield stress 
elástico de cada acero, y este criterio penaliza, obviamente, a los aceros más resistentes (en este caso el dúplex) que quedarán sometidos a un mayor valor de tensión media para un mismo rango de amplitud de tensiones. Una forma muy simple de tener en cuenta el efecto de la tensión media en el comportamiento a fatiga de los materiales es hacer uso de alguna de las expresiones utilizadas para corregir este efecto, como la de Goodman $[3]$, que relaciona la amplitud de tensión aplicada $(\Delta \sigma)$ a una determinada tensión media $\left(\sigma_{m}\right)$, con la que proporcionaría la misma vida a fatiga bajo una tensión media igual a cero $\left(\Delta \sigma_{0}\right)$ : of each product, so that the mean stress applied to the duplex stainless steel bars -whose yield stress was the largest- was higher than the mean stress applied to the other reinforcing bars for the same level of applied stress amplitude. A simple way to take into account the effect of the mean stress on the fatigue behaviour of materials is by the use of the Goodman 's expression [3], that relates the stress amplitude $(\Delta \sigma)$ obtained for any mean stress $\left(\sigma_{m}\right)$, with that which would provide the same fatigue life under a mean stress equal to zero $\left(\Delta \sigma_{0}\right)$ :

$$
\Delta \sigma_{0}=\frac{\Delta \sigma}{\left(1-\frac{\sigma_{m}}{\sigma_{t s}}\right)}
$$

Donde $\sigma_{t s}$ es la resistencia a la tracción del material.

La tabla 5 muestra los límites de fatiga obtenidos experimentalmente para un número de ciclos, $\mathrm{N}$, igual a 2 millones y una probabilidad de fallo del $50 \%$, de los distintos tipos de armaduras de acero inoxidable analizados. Esta misma tabla recoge, asimismo, los valores de $\Delta \sigma_{0}$ obtenidos, tras haber sido corregido el efecto de la tensión media utilizando la ecuación [3].

Una vez eliminado el efecto de la tensión media, los corrugados de acero al carbono son los que muestran el peor comportamiento a fatiga de los cuatro analizados. La resistencia a la fatiga de las barras de acero inoxidable dúplex supera a la correspondiente al austenítico 316LN, pero las barras del inoxidable austenítico 304LN siguen siendo las más resistentes a fatiga. Queremos destacar finalmente, que el límite de fatiga del acero $304 \mathrm{LN}$ es similar al encontrado por otros investigadores (19) para armaduras de acero al carbono corrugadas en frío, cuyas características resistentes son similares a las de este acero, pero con una ductilidad muy inferior.
Where $\sigma_{t s}$ is the tensile strength of the material.

Table 5 shows the fatigue limits experimentally obtained on all the re-bars for $\mathrm{N}=2$ million of cycles and a failure probability of $50 \%$. Table 5 also shows the corresponding $\Delta \sigma_{0}$ values, after the application of the mean stress correction by means of equation [3].

Once removed the effect of the mean stress, the carbon steel bars have the lowest fatigue limit and the duplex steel ones surpass the austenitic $316 L N$, although the fatigue limit of the austenitic 304LN bars are still the highest due to the improved surface morphology of these bars. As a final remark, the fatigue limit of the 304LN bars is similar to the fatigue limit of cold rolled carbon steel rebars, determined by other researchers (19), having tensile strengths similar to this austenitic steel, but with a much lower ductility

Tabla 5 / Table 5

Límites de fatiga ( $\mathrm{N}=2$ millones de ciclos y $\mathrm{P}=50 \%$ ) obtenidos experimentalmente $(\Delta \sigma)$ y tras la corrección de Goodman $\left(\Delta \sigma_{0}\right)$. Fatigue limits ( $N=2$ million cycles and $P=50 \%$ ) experimentally obtained $\left(\Delta \sigma_{0}\right)$.

\begin{tabular}{|c|c|c|}
\hline Acero / Steel grade & $\begin{array}{c}\Delta \boldsymbol{\sigma} \\
\mathbf{N}=\mathbf{2} \cdot \mathbf{1 0}\end{array}$ & $\begin{array}{c}\Delta \mathbf{\sigma}_{\mathbf{0}}(\mathbf{\sigma}=\mathbf{0}) \\
\mathbf{N}=\mathbf{2} \cdot \mathbf{1 0}^{\mathbf{6}}\end{array}$ \\
\hline $304 \mathrm{LN}$ & $255 \mathrm{MPa}$ & $366 \mathrm{MPa}$ \\
\hline $316 \mathrm{LN}$ & $170 \mathrm{MPa}$ & $255 \mathrm{MPa}$ \\
\hline D2205 & $158 \mathrm{MPa}$ & $290 \mathrm{MPa}$ \\
\hline B500SD & $167 \mathrm{MPa}$ & $245 \mathrm{MPa}$ \\
\hline
\end{tabular}

\subsection{Comportamiento frente a la corrosión}

Tras la realización de los ensayos de corrosión y el análisis de las diferentes curvas de polarización obtenidas, la Figura 9 recoge los resultados de la resistencia a la

\subsection{Corrosion behaviour}

After the analysis of the different polarization curves obtained in the corrosion tests, Figure 9 shows the results of the polarization resistance, $\mathrm{R}_{\mathrm{p}}$, obtained on the different 
polarización, $R_{p}$, obtenidos para los diferentes aceros inoxidables (el acero al carbono no ha sido ensayado habida cuenta de que su baja resistencia a la corrosión es sobradamente conocida). Como puede observarse, la resistencia a la polarización de los dos aceros inoxidables austeníticos es muy similar y sensiblemente inferior a la mostrada por el acero inoxidable dúplex, es decir, este último acero tiene una menor velocidad de corrosión en el medio analizado. La explicación a este hecho podría fundamentarse en el mayor contenido en molibdeno del acero inoxidable dúplex. Otros autores han obtenido resultados similares utilizando también soluciones específicas que simulaban el ambiente existente en las porosidades del hormigón $(25,26)$. stainless steels (carbon steel had not been corrosion tested as its low corrosion resistance in this environment is well known). As it is shown, the polarization resistances of the two austenitic stainless steels are very similar and significantly lower than that exhibited by the duplex stainless steel: this latter steel has a lower corrosion rate in the analyzed environment. The explanation for this fact could be based on the higher molybdenum content of the duplex stainless steel. Other authors have also obtained similar results using specific solutions that simulated the environment existing in the porosities of concrete $(25,26)$.

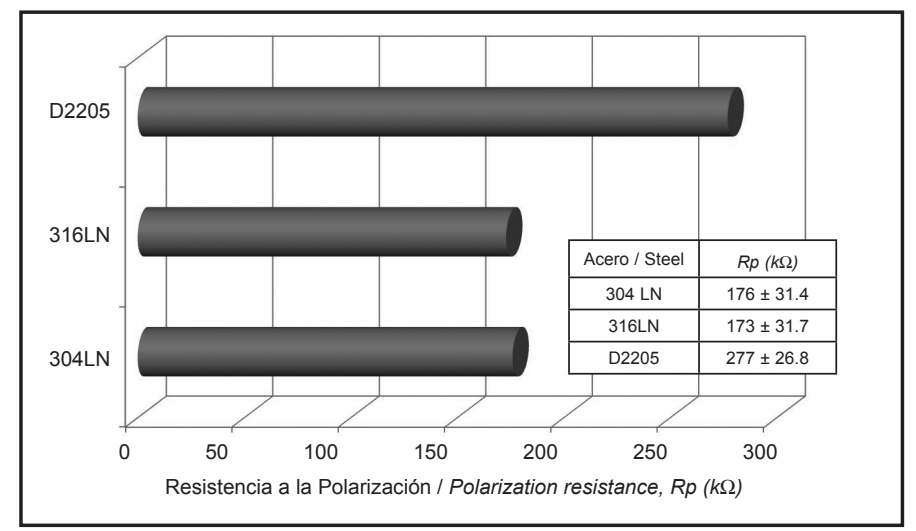

Figura 9. Resistencia de polarización en medio alcalino salino (electrodo de referencia $\mathrm{Ag} / \mathrm{AgCl}$ ) Figure 9. Polarization resistance in saline alkaline environment (Ag/AgCl reference electrode).

\section{CONCLUSIONES}

Las armaduras de acero inoxidable, tanto austenítico cómo dúplex aquí analizadas, muestran una resistencia a tracción, tenacidad y resistencia a la fatiga, al menos similares, y en muchos casos superiores, a las mostradas por las armaduras de acero al carbono de alta ductilidad (B500SD), mostrando asimismo una ductilidad significativamente más elevada, junto con una excelente resistencia a la corrosión en medios salinos.

El proceso de fabricación de las armaduras de acero inoxidable, y más concretamente el estado superficial de las herramientas que las conforman durante la laminación, ha de ser controlado minuciosamente, ya que un mal estado superficial de las mismas, provoca la existencia de defectos superficiales en las barras, que disminuyen mucho su comportamiento a fatiga. Además, el contenido en nitrógeno, añadido con objeto de lograr un endurecimiento por solución sólida y de elementos residuales como el titanio, deben ser estrictamente controlados con objeto de evitar la formación de precipitados de TiN, y asegurar así, un buen comportamiento a fractura y ante solicitaciones de fatiga de las armaduras.

\section{CONCLUSIONS}

The stainless steel rebars, both austenitic and $d u$ plex, analyzed in this work, show a tensile strength, toughness and fatigue resistance, at least similar, and in many cases higher tthan those shown by a carbon steel reinforcement bar with high ductility (B500SD), showing also a significantly higher ductility, together with an excellent corrosion resistance in saline environments.

The manufacturing process of the steel rebars, and more particularly the surface state of the rolling tools, has to be carefully controlled, since a bad surface condition of these tools gives way to the occurrence of surface defects in the bars, which greatly decrease their fatigue behavior. Furthermore, nitrogen -added in this case to achieve a solid solution hardening-and residual elements, such as titanium, must be strictly controlled to avoid the formation of TiN precipitates, and thereby ensure a good fracture and fatigue behavior of the rebars. 
Por último, las barras corrugadas de acero inoxidable dúplex han mostrado una mayor resistencia mecánica y frente a la corrosión en un medio alcalino salino, que la de las fabricadas con acero inoxidable austenítico. Además, los corrugados dúplex presentan una ductilidad y tenacidad muy elevadas y un más que aceptable comportamiento a fatiga, que podría mejorase significativamente llevando a cabo un buen control tanto de las herramientas de conformado de las barras como de los elementos residuales presentes en su composición química.

\section{AGRADECIMIENTOS}

Los autores desean expresar su agradecimiento al gobierno de España, que a través de DGICYT (FEDER 1FD97-1525) financió parte de esta investigación. También desean agradecer a la empresa ROLDAN S.A. por el suministro de las barras corrugadas así como por proporcionarnos toda la información necesaria relativa a su proceso de fabricación.
Finally, the duplex stainless steel rebars showed higher mechanical strength and corrosion resistance in an alkaline saline medium than those made of austenitic stainless steels. Furthermore, duplex rebars exhibited very high ductility and toughness and an acceptable fatigue behavior, which would be still significantly improved by means of an appropriate quality control of both, the tools used in the forming of the bars and the residual elements present in its chemical composition.

\section{ACKNOWLEDGEMENTS}

The authors would like to express their gratefulness to the Spain government for the financing received through project FEDER 1FD97-1525. Also they are thankful to ROLDAN S.A. for the provision of the reinforcing bars used in this work and the information relative to their manufacturing process.

\section{BIBLIOGRAFÍA / BIBLIOGRAPHY}

(1) Basham, K.: "Choices in corrosion-resistant rebar", Concrete Construction, vol. 44, no 10 (1999), pp. 27-33

(2) Smith, E.N.: "The use of stainless steel for concrete reinforcing bars is gaining momentum". Stainless Steel World., vol. 10 (1998), 52-55.

(3) McGurn, J.M.: "Stainless steels reinforcing bars in concrete", Proceedings of the International Conference of Corrosion and Rehabilitation of Reinforced Concrete Structures, Orlando, FL, FHWA, December 1998.

(4) Knudsen, A.: "Cost effective enhancement of durability of concrete structures by intelligent use of stainless steels reinforcement", Proceedings of the International Conference of Corrosion and Rehabilitation of Reinforced Concrete Structures, Orlando, FL, FHWA, December 1998.

(5) Bertolini, L.; Pedeferri, P. y Pastore, T.: "Stainless steel in reinforced concrete structures". Proceedings of the Second International Conference on concrete under Severe Conditions, vol. 1, 21-24, (1998) (published by E\&FN Spon).

(6) The Concrete Society: Concrete Society Technical Report 51, Guidance on the use of stainless steel reinforcement, Concrete Society Steering Committee, 1998.

(7) Ip, A.K.C.; Pianca, F. y Hope, B.B.: "Application of stainless steel reinforcement for highway bridges in Ontario", Nickel-Cobalt'97, Applications and Materials performance, vol. IV (1997), pp. 227-284 (eds: F.N. Smith, J.F. McGurn, G.Y. Lai, V.S Satri) The Metallurgy Society, CIM, Montreal.

(8) Castro, H.; Rodríguez, C.; Belzunce, F.J. y Canteli, A.F. : "Mechanical properties and corrosion behaviour of stainless steel reinforcing bars", Journal of materials processing technology, 143, (2003), pp. 134-137.

(9) BS 6744:2001: "Stainless steel bars for the reinforcement of concrete", 2001.

(10) DS 13 080-1:"Armeringsstal Del 1: Armerinsstal anvent til slapt armerede betonkonstruktioner Krav". Pr $\square$ vning, 1984, Basel, Birkhäuser Verlag.

(11) ASTM E112-96: "Standard Test Methods for Determining Average Grain Size" Annual Book of ASTM standards, vol. 03.01, PA, USA, 2004

(12) ASTM E92-82: "Standard Test Method for Vickers Hardness of Metallic Materials". Annual Book of ASTM Standards, vol. 03.01, PA, USA, 2003.

(13) ISO/CD 15630-1. 2: "Steel for the reinforcement and prestressing of concrete -Test methods- Part 1: Reinforcing bars and wires", 1998.

(14) ESIS P2-92: "ESIS procedure for determining the fracture behaviour of materials" European Structural Integrity Society, Delft, Holland, 1992.

(15) Tosal, L.; Rodríguez, C.; Betegón, C. y Belzunce, F.J.: "The influence of specimen size on the fracture behaviour of a structural steel at different temperatures", Journal of Testing and Evaluation, 28, (2000), pp. 276-281.

(16) Canteli, A.; Esslinger, V. y Thürlimann, B.: "Ermüdungsfestigkeit von Beweherungs-und Spannstählen". (1984) Institut für Baustatik und Konstruction, ETH Zürich. Birkhäuser Verlag. Basel. 
(17) Castillo, E.; Canteli, A. F.; Esslinger, V. y Thürlimann, B.: "Statistical Model for Fatigue Analysis of Wires", Strands and Cables. IABSE Proceedings, (1985), pp. 82-85.

(18) ASTM G59: "Standard test method for conducting potentiodynamic polarization resistance measurements", Annual Book of ASTM standards, Vol.03.02, PA, USA.

(19) McDonald, D., Pfeifer, D. y Virmani, P.: "Corrosion-resistant reinforcing bars findings of a 5-year FHEA study", Proc. of the Int. Conference on Corrosion and Rehabilitation of Reinforced Concrete Structures, Orlando, USA, December 1998.

(20) ASTM E1820-99: "Standard Test Method for Measurement of Fracture Toughness", Annual Book of ASTM standards, 1999.

(21) Joyce, J.A.: Manual on Elastic-Plastic Fracture, ASTM, 1996.

(22) Grinder, D. y Chone, J.: Formation of titanium nitride particles in continuously cast stainless steel products, Ed. N.A. McPherson and A. McLean, 1995.

(23) EN 10080: "Steel for the reinforcement of concrete, Parts 1, 2 and 3", 1999.

(24) McPherson, N.A. y McLean, A. Non-metallic inclusions in continously cast steel. Ed. N.A. McPherson and A McLean. Iron and Steel Society, 1995.

(25) Álvarez, S.M.; Bautista, A. y Velasco, F., Corrosion behaviour of corrugated lean duplex steels in simulated concrete pore solutions. Corrosion Science, 53 (2011), pp. 1748-1755.

(26) Blanco, G.; Bautista, A. y Takemonti H. EIS study of passivation of austenitic and duplex stainless steels reinforcements in simulated pore solutions. Cement\&Concrete Composites, 28 (2006), pp. 212-219. 